\title{
CHILDRENS' BILINGUAL STORY BOOK ANALYSIS USING SHIFT AND LITERAL TRANSLATION
}

\author{
Devi Siti Sihatul Afiah \\ Fakultas Keguruan dan Ilmu Pendidikan, Universitas Swadaya Gunung Jati \\ devy.sitiafiah@gmail.com
}

\begin{abstract}
This reseach aims to know how many shift technique and literal methode used in translating childrens' billingual story book, entititled: Munch!Munch!Munch! publisher Erlangga Kids. To analyze this research, the reseacher used a descriptive qualitative method. Using documents as the data, it taken from the book entittled Munch!, Munch!, Munch! Consists of 28 sentences, then each sentence analyzed using shift technique and literal methode. The results are found 19 shift and 12 literal. Based on the results above, it shows that the translator has tried to translate this book seriously. It means she/he tried getting meaning of source language readable and natural. Unfortunately, the translator is still inconsistent in choosing meaning of target language. E.g there are some plural words but only a few of plural that translated in plural too. There is the singular word but transaltor translate it to plural. In my opinion, the writer who involve the translator (only has english knowlede does not has transaltion knowldge) should learn translation materials. It will help her/him to make good translating. It means the translator will find the meaning in source language more readable, natural and accurate.
\end{abstract}

Keywords: Billingual story; Children's book; Literal; Shift; Translation.

\section{INTRODUCTION}

In Indonesia so many childrens' story book using bilingual. Lots of childrens' story books came from foreign then translator translate it into indonesian. Besides, lots of childrens' story book came from Indonesia itself. Dilebretly the writer make childrens' story book using billingual. This phenomenon occurs becuase so many parents want their children master in english since early stage.

Therfore, many writers make childrens' story book using bilingual. In this process the writer also often become a translator. The process of transfering meaning from one language into other language called translation process. According to Larson (1977:10) translation in the transfer of meaning in the source language tex $t$ into the target text, this is done by replacing the form of the first language by the form of the second language. The meaning itself is maintained as the form may be adjusted by transferring the meaning of SL text by the use of very natural forms in the TL. In line with above, Newmark (1981: 7) said that translation is a craft in the attempt to replace a written message and /or statement in one language by the same message and /or statement in another language. Each exercise involves some kinds of loss of meaning, due to a number of factors. It provokes a continuous tension, a dialectic, an argument based on the claims of each language. The basic loss is on a continuum between overtranslation (increased detail) and undertranslation (increased generalization).

A translator have to expert to find out the natural meaning in the source language. From lots of procedure and method in translation, shift and literal 
translation often used by translator. According to Catford (1978: 73) states that by shift, we mean the departure is made of from formal correspondence in the process of going from the source language to the target language. Shifts occur when the source language text is translated into different grammatical or phonological form in the target language text. Besides, Newmark (1988: 85) said that a shift is translation procedure invloving a change in the grammar from source language to target language.

According to experts above that shift procedure expalin about grammatical system. As we know that Indonesian grammatical system is diffrent with English. Such as, the use of lingking verb, determiner, plural word, part of speech, etc. So, in this case the translator have to know how to translate the source language intii target language raedable by reader.

Beside shift procedure, the reasecher using litral translation as method in analyzing the data. According to Newmark (1988: 81) said that Literal translation: in which the SL grammatical constructions are converted to their nearest $T L$ equivalents, but the lexical words are again translated singly, out of context. This method made the translator to find out the suitable meaning in source language. How to make it naturalness and readable. How to make the reader understand what the meaning of the sentence.

\section{RESEARCH METHODOLOGY}

Reseacher used the a descriptive qualitative method to study shift and literal translation in translating childrens, bilingual story book entitled; Munch!, Munch!, Munch! Written by Merlinda Lesmana, published by Erlangga for kids. 2008.

According to Creswell in Sugiyono (2015) said that qualitative research is a means for exploring and understanding the meaning individuals or groups ascribe to social or human problem. The process of research involves emerging questions and procedures; colecting data in the participants's setting; analyzing the data inductively, building from particulars to general themes; and making interpretations of the meaning of data. The final written repot has a flexible writing structure.

The researcher using document as the data, it taken from the text of childrens' bilingual story book entitled; Much!Munch!Munch!; Nyam! Nyam! Nyam. Then, reseacher analyzed it per sentence of the text.

In analyzing data, reseacher clasify it into sentences. In this book there are 28 sentences. After clasfying each sentence, it is analyzed using shift and literal translation.

\section{RESULT AND DISCUSSION}

There 28 sentences in this book. The reseacher analysis the data using shift and literal translation. Therer are some sentences was not found shift and literal transaltion.

Table 1. of Shift and Literal Analysis

\begin{tabular}{cccc}
\hline No & Data & Shift & Literal \\
\hline 1 & Data 1 & 1 & - \\
\hline 2 & Data 2 & - & - \\
\hline 3 & Data 3 & 1 & 1 \\
\hline 4 & Data 4 & - & 1 \\
\hline 5 & Data 5 & - & 1 \\
\hline 6 & Data 6 & 1 & 1 \\
\hline 7 & Data 7 & - & 1 \\
\hline 8 & Data 8 & 1 & - \\
\hline 9 & Data 9 & - & 1 \\
\hline 10 & Data 10 & 2 & - \\
\hline 11 & Data 11 & 1 & - \\
\hline 12 & Data 12 & 1 & - \\
\hline 13 & Data 13 & 1 & - \\
\hline 14 & Data 14 & 1 & - \\
\hline 15 & Data 15 & 1 & - \\
\hline 16 & Data 16 & 1 & - \\
\hline 17 & Data 17 & 1 & - \\
\hline 18 & Data 18 & - & 1 \\
\hline 19 & Data 19 & - & 1 \\
\hline & & &
\end{tabular}




\begin{tabular}{llll}
\hline 20 & Data 20 & 1 & - \\
\hline 21 & Data 21 & 1 & - \\
\hline 22 & Data 22 & - & 1 \\
\hline 23 & Data 23 & - & 1 \\
\hline 24 & Data 24 & 1 & - \\
\hline 25 & Data 25 & - & 1 \\
\hline 26 & Data 26 & - & 1 \\
\hline 27 & Data 27 & 1 & - \\
\hline 28 & Data 28 & 1 & - \\
\hline 29 & Data 29 & 1 & - \\
\hline & TOTAL & 19 & 12 \\
\hline
\end{tabular}

The table above will explains bellow:

\section{Data 1}

SL: Lala the koala is always hungry. (Munch! Munch! Munch!). she likes to eat laves.

TL: Lala koala selalu lapar (Nyayam! Nyam! Nyam!). ia suka sekali makan dundaunan.

Structure shift, sentence to sentence. Here, translator did not translated lingking verb is (adalah), because if it is translated will make the reader be confused.

\section{Data 2}

SL: One day, she sees an ad in a torn newspaper about doughnuts.

$T L$ : Suatu hari, lala melihat iklan tentang donat di sepotong surat kabar.

\section{Data 3}

SC: Then, she decides she will no longer eat leaves

$T L$ : Lalu, ia memutuskan untuk berhenti makan daun.

Intr- system shifts, leaves show plural but daun shows singular.

Literal transation. No longer means tidak lebih panjang if translated word by word. But in this sentence translator try to give meaning readable by reader in target language.

\section{Data 4}

SL: She wants to try the doughnut now.

$T L$ : Ia ingin makan donat.
Literal translation. Wants to try tanslated makan. The translator find out the natural meaing in source language.

\section{Data 5}

SL: Lala goes to see Joe the Kangaro, and ask him about eating doughnuts.

TL: Lala pergi bertemu Joe si Kanguru, dan menanyakan pendapatnya mengenai makan donat.

Literal Translation, ask him has meaning bertanya pada dia if it is translated word by word. But translator using literal translation in translating it. So bertanya pada dia/nya becomes menamyakan pendapatnya.

\section{Data 6}

SL: Joe has never heard about doughnuts.

$T L$ : Joe tidak tau apa itu donat.

Intr-system shift. Changing the plural to singular. Dougnuts become donat.

Literal translation, never heard about doughnuts has meaning tidak pernah mendengar tentang macam-macam donat if it is translated word by word. But translator using literal translation to make ir readable by reader in target language. Tidak pernah mendengar becomes tidak tau apa itu donat.

\section{Data 7}

SL: He does not seem to care.

$T L$ : Joe juga terlihat tak peduli.

Literal translation. If it does not use literal translation, it will has meaning dia tidak terlihat peduli. But the translator consider the naturalness, so he/she translate it becomes terlihat tidak peduli.

\section{Data 8}

SL: He is happy eating grass and some fruits.

TL: ia senang makan rumput dan buahbuahan.

Structure shift. Sentence to sentence. Is as a linking verb is not translated by translator. It aims to make the the traget language is natural. 


\section{Data 9}

SL: Lala goes to see Poly the Platypus, and ask her about eating doughnuts.

$T L$ : Lala pergi bertemu dengan Poly si Platipus, dan menanyakan pendapatnya tentang makan donat.

Literal translation. Ask her translated menanyakan pendapatnya. If its translated using word by word, it has meaning menanyakannya, but it ambigous for reader.

Data 10

SL: Poly has heard about sweet doughnuts.

$T L$ : Poly pernah mendengar tentang donat yang manis.

Intr-system shift, changing from plural to singular. Doughnuts become donat.

Structure shift. Sweet dougnuts has meaning manis donat if it is translated word by word. But translator using structure shift in translating it. So it's meaning becomes donat yang manis.

\section{Data 11}

SL: She thinks doughnuts will be too sweet for her.

$T L$ : Poly fikir donat terlalu manis untuknya.

Unit shift, 2 words become 1 word. For her become untuknya.

\section{Data 12}

SL: She would prefer small fish and some insects for her snacks.

$T L$ : Ia lebih suka makan ikan-ikan kecil dan serangga.

Intra-system shift, singgular change to plural. Fish become ikan-ikan. And from pluran change to singular, insects become serangga.

\section{Data 13}

SL: Lala goes to see Wolly the wombat.

$T L$ : Lala pergi bertemu dengan wolly si Wombat

Structural shft. Word become clause. Wolly becomes dengan wolly.

\section{Data 14}

SL: Lala asks Wolly whether he would go with her to a town to buy doughnuts.

$T L$ : Lala mengajak Wolly pergi ke kota membeli donat.

Structure shift, a as a determiner is not translated by translator. It will make the target language is not natural. To a town become ke sebuah kota.

Intra-system shift, plural change to singular, doughnuts becomes donat.

\section{Data 15}

SL: Wolly is afraid to go

$T L$ : Woly tidak mau pergi

Structure shift, changing from sentence to phrase.

\section{Data 16}

SL: He tells story about his cousin that once was hit by a car on the way to the town.

$T L$ : Ia kemudian menceritakan sepupunya yang tertabrak mobil saat pergi ke kota.

Structural shift. Determiner a is not translated by translator. A car translated mobil, sebuah mobil is not natural in source language.

Data 17

SL: So he would rather stay in the bush, eating grass and roots.

$T L$ : Wolly lebih suka tinggal di semaksemak dan memakan rumput serta akarakaran.

Intra-shift system. Bush (singular) translated semak-semak (plural)

\section{Data 18}

SL: Lala goes to see Amy the emu.

TL: Lala pergi menemui Ami si burung Emu.

Litreal translation. The translated si. Literally the has no meaning, but coceptually the as afirmation for the next word, si as afirmation for Emu (bird name). 
Data 19

TL: Maybe Amy will have courage to go to the town with Lala.

$S L$ : Ia berharap Amy cukup berani pergi bersamanya ke kota.

Literal translation, amy will have courage has meaning amy akan memiliki berani if it is translated word by word. But here, translator translate it becomes amy cukup berani. The aim is to make it readable by reader in target language.

\section{Data 20}

TL: However, Amy is busy today.

SL: Tapi, hari ini Amy sangat sibuk.

Structure shift, is as a lingking verb is not translated by translator beacause it will make ambigous. Amy adalah sangat sibuk.

\section{Data 21}

SL: she has promised her brother that she will teach him how to play boomerang.

$T L$ : Ia sudah berjanji pada adiknya untuk mengajari cara bermain bumerang.

Structural shift. Sentence changes phrase. She will teach him how to play boomerang becomes mengajari cara bermain bumerang.

\section{Data 22}

SL: Finally, Lala decides that she will go to town, herself.

TL: Akhirnya, Lala memutuskan untuk pergi ke kota sendirian.

Literal translation. That she will go translated to memutuskan untuk pergi. If it is translated wor by word, it should be bahwa dia akan pergi, but according to translator that's meaning is not natural in target language.

\section{Data 23}

SL: She brings one dollar coin that she found in the bush and has kept it for some times for emergency needs.

$T L$ : Ia membawa koin satu dolar yang dulu ia temukan disemak-semak dan ia simpan untuk berjaga-jaga.
Literal translation. For emergency needs has meaning untuk darurat. But here, the translator translate it becomes untuk berjaga-jaga. It is more natural for reader in target language.

\section{Data 24}

SL: At the doughnuts shop, Lala wears a clown costume.

$T L$ : Di toko donat, Lala mengenakan kostum badut.

Structural shift, a as determiner is not translated by translator. If it is done, it will make ambigou. a clown costume becames sebuah kostum badut.

\section{Data 25}

SL: She gives sign to the shop keeper that she wants to buy a donut, and she pays \$1 for it.

$T L$ : Ia memberikan tanda bahwa ia ingin membeli donat, dan ia memberikan koin satu dolarnya.

Literal translation. \$1 for it translated satu dolarnya. If it is translated word by word, it has meaning untuknya. And untuknya is ambigous for the reader.

\section{Data 26}

SL: Lala opens the box, smells the sweet doughnut, and eats...

$T L$ : Lala membuka kotak donat, mencium baunya, dan kemudian memakannya.

Literal translation. Smells the sweet doughnut is transnlated to mencium baunya. If the translator using word by word translation, it will be bau manis donat. It is very ambigous in target language.

\section{Data 27}

SL: Munch!Munc!Much!, Lala the koala is munching some leaves.

TL: Nyam! Nyam! Nyam, Lala si Koala asyik mengunyah daun.

Intera-system shift, changing from plural to singgular. Leaves become daun. 
Data 28

SL: Now she knows that she prefers eating leaves than doughnut.

$T L$ : Sekarang ia tahu, ia lebih suka makan daun daripada donat.

Intera-system shift, changing from plural to singgular. Leaves become daun.

\section{Data 29}

SL: Please help Lala find the way to the doughnut shop!

TL: Bantu Lala agar sampai ke toko donat! Structure shift. Changing from sentence to phrase.

\section{CONCLUSION}

The translator of childrens' bilingual story book entitled: Munch! Munch! Munch had tried to translate it naturally. How the reader understand the messege of that book easily. It can be seen from how the translator use the literal translation as the method to translate the target language to source language. Then, many findings in this study show how the translator tried to use shift in this transalting. Based on the results above, it shows transaltor had tried to get target source meaning which readable and naturalness.

But unfortunately, the translator is still inconsistent in choosing meaning of target language. E.g there are some plural words but only a few of plural that translated in plural too. There is the singular word but transaltor translate it to plural.

In my opinion, the writer who involve the translator (only has english knowlede does not has transaltion knowldge) should learn translation materials. It will help her/him to make good translating. It means the translator will find the meaning in source language more readable, naturalness and accurate.

\section{Refferences}

Abdul Munif. 2008. Thesis; Pergeseran dalam Penerjemahan Klausa Pasif dari Novel Lord of the Rings. UNS. Surakarta.

Elfast. 2009.Translation. Pare

Lesmana, Merlinda. 2008. Munch!Munch!Munch!. Erlangga.

Newmark, Peter. 1988. A Textbook of Translation.

Prentice Hall International Ltd. UK

Robinson. A Douglas. 2003. Becoming a Translator. MPG Books Ltd. New York.

Sugiyono. 2005. Metode Penelitian dan Pengembangan; Research and Development. Bandung: Alfabeta. 